\title{
COMPARATION BETWEEN PULSED Nd:YAG LASER SUPERFICIAL TREATMENT AND CERAMIC COATING IN CREEP TEST OF Ti-6AI-4V ALLOY
}

\author{
Reis, A.G. ${ }^{1, a}$; Reis, D.A.P. ${ }^{1, b}$; Moura Neto, C. ${ }^{1, c} ;$ Onõro, J. ${ }^{2, d}$; \\ Oliveira, H.S. ${ }^{1, \mathrm{e}}$; Couto, A.A. ${ }^{3,4, \mathrm{f}}$ \\ ${ }^{1}$ Instituto Tecnológico de Aeronáutica, Divisão de Eng. Mecânica, S. J. Campos, Brazil. \\ ${ }^{2}$ Universidade Politécnica de Madrid, UPM, Madrid, Espanha. \\ ${ }^{3}$ Instituto de Pesquisas Energéticas e Nucleares, IPEN, São José dos Campos, Brazil \\ ${ }^{4}$ Universidade Presbiteriana Mackenzie, Săo Paulo, Brasil. \\ a adriano.g.reis@hotmail.com, bdanielireis@hotmail, 'mneto@ita.br, djavier.onoro@upm.es, ${ }^{\text {e }}$ \\ helder.so@hotmail.com, ${ }^{\circ}$ acouto@ipen.br
}

Keywords: creep, plasma-sprayed coatings, pulsed laser, titanium alloy.

Abstract: The objective of this work was evaluating the creep resistance of the Ti-6Al-4V alloy with superficial treatment of pulsed Nd:YAG laser and ceramic coating in creep test of Ti-6Al-4V alloy. It was used Ti-6Al-4V alloy as cylindrical bars under forged and annealing of $190^{\circ} \mathrm{C}$ by 6 hours condition and cooled by air. The Ti-6Al-4V alloy after the superficial treatment of pulsed Nd:YAG laser and ceramic coating was submitted to creep tests at $600^{\circ} \mathrm{C}$ and 125 at $319 \mathrm{MPa}$, under constant load mode. In the Nd:YAG pulsed laser treatment was used an environment of $40 \%$ $\mathrm{N}$ and $60 \% \mathrm{Ar}$, with $2.1 \mathrm{~W}$ of power and $10 \mathrm{~m} / \mathrm{s}$ of speed. Yttria ( $8 \mathrm{wt} . \%$ ) stabilized zirconia (YSZ) with a CoNiCrAlY bond coat was atmospherically plasma sprayed on Ti-6Al-4V substrates by Sulzer Metco Type $9 \mathrm{MB}$. The obtained results suggest the laser treatment on Ti-6Al-4V alloy improved its creep resistance.

\section{Introduction}

Development of alloys to increase creep strength, so permitting the use of higher turbine entry temperatures, has resulted in a general reduction in chromium and increase in aluminum content of nickel superalloys. This has had relatively little effect on high-temperature oxidation resistance, but has had a very significant adverse effect on corrosion resistance in the lower temperature range in salt-contaminated environments. Such environments are experienced by aircraft operating between airfields with approaches low over the sea with relatively short sector times. Improvements in aero gas turbine performance in terms of power, efficiency and weight have necessitated the use of high specific-strength, low-density materials $[1,2]$. 
One of the major factors limiting the life of titanium alloys in service is their degradation due to gaseous environments, in particular, the one containing oxygen, especially at elevated temperatures, during the long term use [3]. The sensitivity of titanium alloys to high temperature exposure is a well-known phenomenon. When titanium alloys are heated to temperatures above approximately $800^{\circ} \mathrm{C}$, oxygen, hydrogen and nitrogen penetrate into them. The penetration of the above elements is thought to be undesirable because it increases hardness and brittleness while decreasing the toughness of the alloy [4]. Interaction of titanium alloys with oxygen not only causes loss of the material by formation of oxides, but also causes embrittlement in the subsurface zone of the component due to oxygen enrichment [3].

Titanium alloys is one of the most technologically important materials in the aeronautic and aerospace field for its high strength and lightweight. However, this material does not possess satisfactory tribological property. For this reason, surface strengthening of titanium alloys has attracted much attention [5].

Laser oxidation or nitridation of titanium surfaces are interesting for local hardening and improvement of wear resistance. It is known that melting of the surface layer to enhance the chemical reactions, avoiding significant vaporization and particulates removal, represents the main requirement in direct laser surface oxidation or nitridation of metallic targets in controlled reactive atmospheres [6,7].

To prevent the superficial oxidation and in the grain boundary the sample is plasma sprayed coated Yttria (8wt\%) stabilized zirconia (YSZ) with CoNiCrAlY (AMDRY 995C), an technique studied recently named thermal barrier coating (TBC). The YSZ ceramic coating, which is the outer layer, is used to insulation and the CoNiCrAlY metallic coating, which is the inner layer, prevent corrosion/oxidation at high temperatures and stick the YSZ ceramic coating to the titanium alloy. These characteristics provide an improvement in the creep resistance [8-12].

The aim of the present paper was to measure the creep resistance of the Ti-6Al-4V alloy with superficial treatment of pulsed Nd:YAG laser and ceramic coating in creep test of Ti-6Al-4V alloy. A substantial part of the creep research has been devoted to Ti-6Al-4V due to its industrial and technological importance.

\section{Experimental Procedure}

The chosen material for the present study was hot-forged $12.7 \mathrm{~mm}$ diameter rod of commercial Ti-6Al-4V alloy with the same specifications as published by ASTM [13]. The microstructure (Fig. 1) consists of equiaxed $\alpha$ grains with average size about $10 \mu \mathrm{m}$. The transformed $\beta$ phase is present 
in the $\alpha$ grain boundaries [14]. Tensile testing was performed at $600^{\circ} \mathrm{C}$ in air according to ASTM standard E 21 specification [15]. The tensile properties are summarized in Table 1 namely, $0.2 \%$ yield stress (YS), ultimate tensile stress (UTS), elongation (EL) and reduction of area (RA). The initial creep stress levels were determined from the elevated temperature tensile properties given in Table 1. The Nd:YAG laser treatment parameters used are presented in Table 2, it was used ROFIN DY 033 laser and Talymap Silver 4.0 software. Yttria (8 wt.\%) stabilized zirconia (YSZ) (Metco 204B-NS) with a CoNiCrAlY bond coat (AMDRY 995C) was atmospherically plasma sprayed on Ti-6Al-4V substrates by Sulzer Metco Type 9 MB. Constant load creep tests were conducted with Ti-6Al-4V alloy at $600^{\circ} \mathrm{C}$. The creep tests were conducted on a standard creep machine at stress of 250 and $319 \mathrm{MPa}$. Samples with a gauge length of $18.5 \mathrm{~mm}$ and a diameter of $3.0 \mathrm{~mm}$ were used for all tests. The creep tests were performed according to ASTM E139 standard [16].

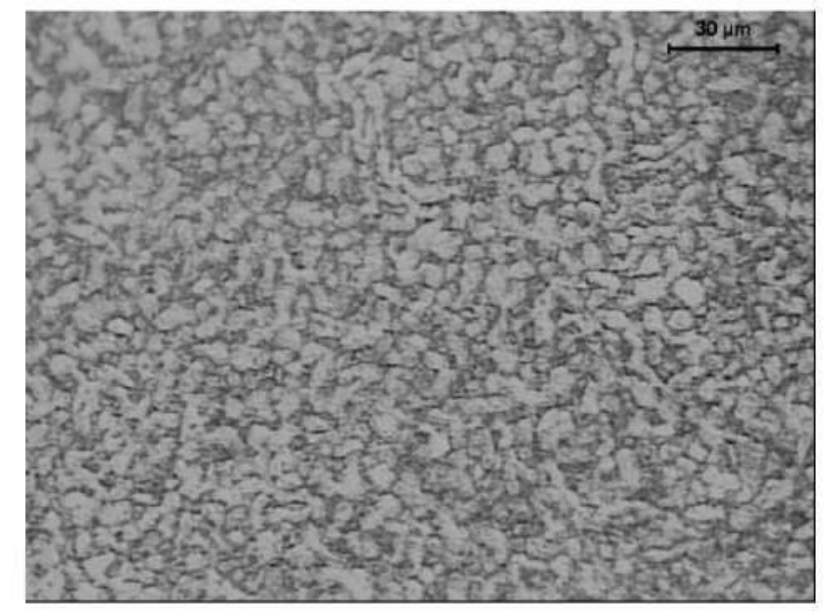

Fig. 1. Micrograph of Ti-6Al-4V alloy as-received.

Table 1 - Tensile properties of Ti-6Al-4V alloy.

\begin{tabular}{ccccc}
\hline $\mathrm{T}\left[{ }^{\circ} \mathrm{C}\right]$ & YS [MPa]) & UTS [MPa] & EL [\%] & RA [\%] \\
\hline 600 & 377 & 407 & 46 & 85.7 \\
\hline
\end{tabular}

Table 2 - Laser treatment parameters.

\begin{tabular}{|c|c|}
\hline Parameters & Nd-YAG Laser \\
\hline Power & $1.6-10 \mathrm{~W}$ \\
\hline focal length lens & $100-160 \mathrm{~mm}$ \\
\hline laser scanning speed & $50 \mathrm{~mm} / \mathrm{s}$ \\
\hline environment & $40 \% \mathrm{~N}+60 \% \mathrm{Ar}$ \\
\hline depth above the specimen surface & $0.2-4.5 \mu \mathrm{m}$ \\
\hline $\begin{array}{c}\text { distance between focusing lens - } \\
\text { target }\end{array}$ & $89 \mathrm{~mm}$ \\
\hline laser pulsed energy & $1.9-9.0 \mathrm{~mJ}$ \\
\hline diameter laser spot & $0.17-0.98 \mathrm{~mm}$ \\
\hline
\end{tabular}




\begin{tabular}{|c|c|}
\hline diameter central zone & $0.04-0.24 \mathrm{~mm}$ \\
\hline incident laser intensity & $3.1 \times 109 \mathrm{~W} / \mathrm{cm} 2$ \\
\hline distribution & Gaussian \\
\hline
\end{tabular}

\section{Results}

Representative creep curves of Ti-6Al-4V are showed in Fig. 2.

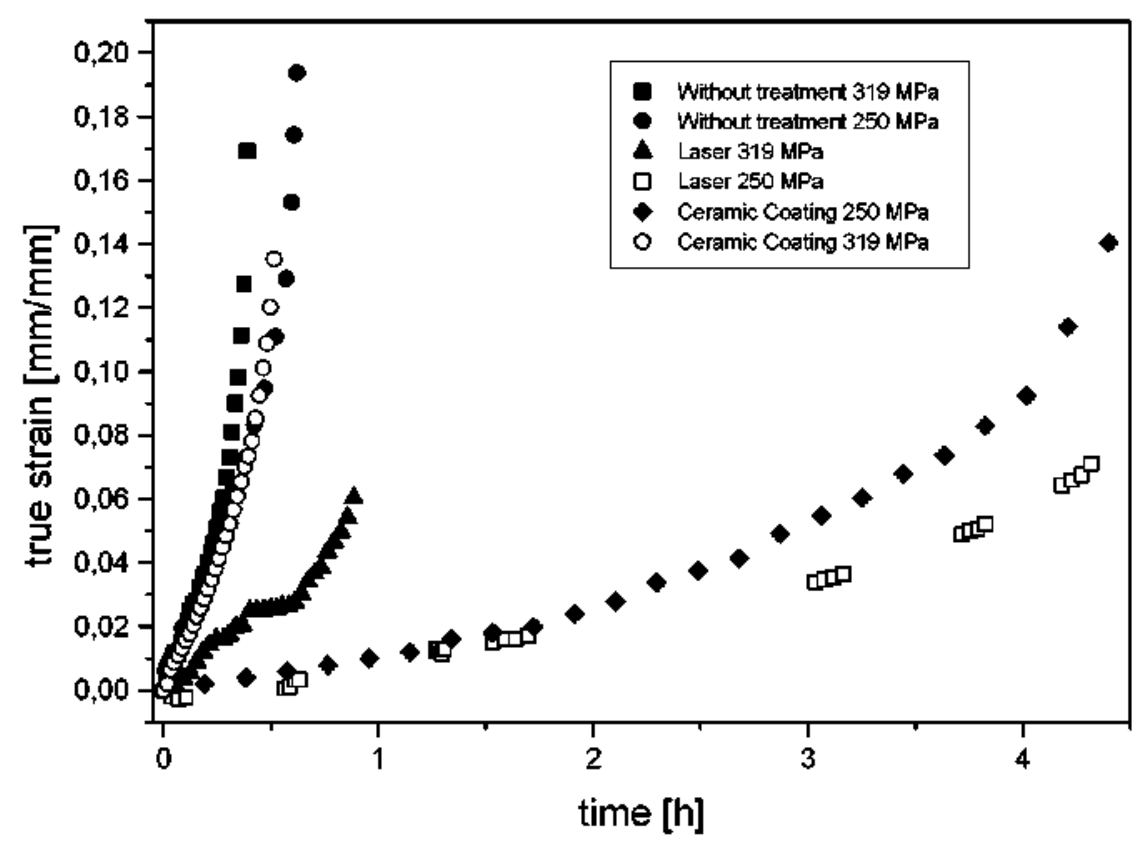

Fig. 2. Typical creep curves of Ti-6Al-4V at $600^{\circ} \mathrm{C}$.

Results from the creep tests at $600^{\circ} \mathrm{C}$ are summarized in Table 3, which shows the values of stress $(\sigma)$, primary creep time $\left(t_{p}\right)$, secondary creep rate $\left(\varepsilon_{s}^{\prime}\right)$, final creep time $\left(t_{f}\right)$, final strain $\left(\varepsilon_{f}\right)$ and reduction of area (RA).

Figure 2 shows that most of the creep life of this alloy is dominated by a constant creep rate that is thought to be associated with a stable dislocation configuration due to recovery and hardening process $[9-10,17]$. The higher creep resistance of Ti-6Al-4V is observed in laser treated samples in all cases.

The reduction of the steady-state creep rate (Table 3) demonstrates that the higher creep resistance of Ti-6Al-4V is observed in laser treated samples. This fact is related to the hardening superficial formed in Ti-6Al-4V alloy by the laser treatment. It is a well known fact that hard surface and interstitial solid solutions increase the creep resistance of certain alloys. The hardening superficial during creep tests, increases rupture life. It is possible that controlled penetration of oxygen into the alloy $\mathrm{Ti}-6 \mathrm{Al}-4 \mathrm{~V}$ could increase its creep resistance without seriously altering its ductility [4]. 
Table 3 - Creep data at $600^{\circ} \mathrm{C}$.

\begin{tabular}{|c|c|c|c|c|c|c|}
\hline Treatment & $\begin{array}{c}\sigma \\
{[\mathrm{MPa}]}\end{array}$ & $\begin{array}{l}\text { tp } \\
{[h]}\end{array}$ & $\begin{array}{c}\varepsilon \cdot \mathrm{s} \\
{[1 / \mathbf{h}]}\end{array}$ & $\begin{array}{l}\text { tf } \\
{[h]}\end{array}$ & $\begin{array}{c}\text { ef } \\
{[\mathrm{mm} / \mathrm{mm}]}\end{array}$ & $\begin{array}{l}\text { RA } \\
{[\%]}\end{array}$ \\
\hline $\begin{array}{l}\text { Without } \\
\text { treatment }\end{array}$ & \multirow{3}{*}{250} & 0.03 & 0.1906 & 0.62 & 0.1938 & 75.83 \\
\hline Ceramic coating & & 0.38 & 0.0104 & 4.59 & 0.1490 & 71.91 \\
\hline Laser & & 0.63 & 0.0127 & 4.32 & 0.0711 & 12.73 \\
\hline $\begin{array}{l}\text { Without } \\
\text { treatment }\end{array}$ & \multirow{3}{*}{319} & 0.01 & 0.5698 & 0.39 & 0.1742 & 62.99 \\
\hline Ceramic coating & & 0.03 & 0.1401 & 0.51 & 0.1353 & 69.75 \\
\hline Laser & & 0.21 & 0.0357 & 0.92 & 0.0627 & 11.51 \\
\hline
\end{tabular}

\section{Conclusions}

Constant load creep tests were conducted with Ti-6Al-4V alloy at $600^{\circ} \mathrm{C}$ and stress of 250 and $319 \mathrm{MPa}$. When the Ti-6Al-4V laser treated alloy was tested the effect of the oxidation was smaller and the behavior of the creep curves showed that the life time was better. There was an increasing of life time. Occurred a decreasing of steady state creep in function of the reduction of oxidation process, showing that for the Ti-6Al-4V alloy their life time was strongly affected by the superficial treatment that was submitted because the oxidation suffered by the material.

\section{Acknowledgment}

FAPESP, CAPES and CNPq for financial support.

\section{References}

[1] G.W. Meetham: Materials Science and Technology Vol. 2 (1986), p.290.

[2] I. Gurrappa and A.K. Gogia: Surface and Coatings Technology Vol. 139 (2001), p.216.

[3] K.V. Sai Srinadh, and K.V. Singh: Bull. Mater. Sci. Vol. 27 (2004), p. 347.

[4] A. Rosen, and A. Rottem: Mater. Sci. Eng. Vol. 22 (1976), p. 23.

[5] X. Chen, G. Wu, R. Wang, W. Guo, J. Yang, S. Cao, Y. Wang, and W. Han: Surface \& Coatings Technology Vol. 201 (2007), p. 4843.

[6] E. György, I.N. Mihailescu, P. Serra, A. Pérez del Pino and J.L. Morenza: Surface and Coatings Technology Vol. 154 (2001), p. 63.

[7] E. György, P. Serra, A. Pérez del Pino and J.L. Morenza: Surface and Coatings Technology Vol. $173(2003)$, p. 265. 
[8] D.A.P. Reis, C.R.M. Silva, M.C.A. Nono, M.J.R. Barboza, F. Piorino Neto, E.A.C. Perez: Materials at High Temperatures Vol. 22 (2006) p. 449.

[9] M. J. R. Barboza, C. Moura Neto, and C.R.M. Silva: Mater. Sci. Eng. A Vol. 369 (2004), p. 201.

[10] D.A.P. Reis, C.R.M. Silva, M.C.A. Nono, M.J.R. Barboza, F. Piorino Neto and E.A.C. Perez: Mater. Sci. Eng. A Vol. 399 (2005), p. 276.

[11] M.J.R. Barboza, E.A.C Perez, M.M. Medeiros, D.A.P. Reis, M.C.A Nono, F. Piorino Neto and C.R.M. Silva: Mater. Sci. Eng. A Vol. 428 (2006), p. 319.

[12] D.A.P. Reis, C. Moura Neto, C.R.M. Silva, M.J.R. Barboza and F. Piorino Neto: Mater. Sci. Eng. A 486 (2008), p. 421.

[13] E.B. Howard and L.G. Timothy in: "Metals Handbook" (Desk edition, ASM International, 1985).

[14] D. Lee, S. Kim, S. Lee and C.S. Lee: Metall.and Mater.Trans. A Vol. 32 (2001), p. 315.

[15] Annual Book of ASTM Standards in: "American Society of Testing and Materials". Philadelphia, PA, 03.01, (1995), p. 129-136.

[16]. Annual Book of ASTM Standards in: "American Society of Testing and Materials". Philadelphia, PA, 03.01, (1995), p. 257-267.

[17] B.F. Dyson and M. Mclean: ISIJ Int. Vol. 30 (1990), p.802. 